\title{
Perception of parents about the auditory attention skills of his kid with cleft lip and palate: retrospective study
}

\section{Percepção dos pais sobre a habilidade de atenção auditiva de seu filho com fissura labiopalatina: estudo retrospectivo}

\author{
Mariza Ribeiro Feniman', Taísa Cristina de Souza², Thais Sanches Teixeira², Maria Fernanda Capoani Garcia Mondelli . \\ 1) Postdoctoral in Audiology from the University of Cincinnati - Ohio - United States. Titular Professor of Phonoaudiology Department at Odontology College of Bauru \\ - USP. \\ 2) Speech therapist graduated by Bauru Odontology College - USP. (Speech Therapist) \\ 3) Doctor in Communication Disorders for HRAC-USP. (Doctor Professor of Phonoaudiology Department at Odontology College of Bauru - USP.) \\ Institution: Odontology College of Bauru - São Paulo University. \\ Bauru / SP - Brazil. \\ Mailing address: Maria Fernanda Capoani Garcia Mondelli - Octavio Pinheiro Brisolla, Alameda 9-75 - Vila Universitária - Bauru / SP - Brazil - Zip Code: $17012-901$ - Telephone: \\ (+55 14) 3235-8232. \\ Article received in 2011 March $09^{\text {th }}$. Article approved in 2011 May $24^{\text {th }}$.
}

\section{SUMMARY}

Introduction: To process and decode the acoustic stimulation are necessary cognitive and neurophysiological mechanisms. The hearing stimulation is influenced by cognitive factor from the highest levels, such as the memory, attention and learning. The sensory deprivation caused by hearing loss from the conductive type, frequently in population with cleft lip and palate, can affect many cognitive functions - among them the attention, besides harm the school performance, linguistic and interpersonal.

Objective: Verify the perception of the parents of children with cleft lip and palate about the hearing attention of their kids.

Method: Retrospective study of infants with any type of cleft lip and palate, without any genetic syndrome associate which parents answered a relevant questionnaire about the auditory attention skills.

Results: 44 are from the male kind and 26 from the female kind, $35,71 \%$ of the answers were affirmative for the hearing loss and $71,43 \%$ to otologic infections.

Conclusion: Most of the interviewed parents pointed at least one of the behaviors related to attention contained in the questionnaire, indicating that the presence of cleft lip and palate can be related to difficulties in hearing attention.

Keywords: attention, hearing, cleft palate.

\section{RESUMO}

Introdução: Para processar e decodificar o estímulo acústico são necessários mecanismos cognitivos e neurofisiológicos. O estímulo auditivo sofre influências de fatores cognitivos de nível mais alto, tais como a memória, atenção e aprendizagem. A privação sensorial ocasionada por perda auditiva do tipo condutiva, frequente na população com fissura labiopalatina, pode afetar várias funções cognitivas - dentre elas a atenção, além de prejudicar os desempenhos escolares, linguísticos e interpessoais.

Objetivo: Verificar a percepção dos pais de crianças com fissura labiopalatina sobre a atenção auditiva de seus filhos. Método: Estudo retrospectivo de crianças com qualquer tipo de fissura labiopalatina, sem qualquer síndrome genética associada cujos pais responderam a um questionário pertinente sobre a habilidade de atenção auditiva.

Resultados: 44 são do gênero masculino e 26 do gênero feminino, $35,71 \%$ das respostas foram afirmativas para a presença de perda auditiva e 71,43\% para infecções otológicas. Conclusão: A maioria dos pais entrevistados apontou pelo menos um dos comportamentos relacionados à atenção contidos no questionário, indicando que a presença de fissura labiopalatina pode estar relacionada com dificuldades quanto à atenção auditiva.

Palavras-chave: atenção, audição, fissura palatina. 


\section{INTRODUCTION}

Anatomical and physiological integrity of auditory system, the maturation of auditory pathways and the adequate sound stimulation are essential to the acquisition and development of oral language (1).

The hearing disorders can be constituted of an isolated clinical condition or can be associated to others changes. Among the changes found that are associated to hearing, we'd highlighted the cleft lip and palate (FLP). The congenital FLP develop themselves during the embryonic period and the beginning of fetal period, being represented, clinically, by the absence of the closure of the lips, palate or both (2). It is estimated that to each 1000 individual born alive, one is a carrier of some kind of cleft lip and palate (3).

In order to process and decode the acoustic stimulus are necessary several processes, cognitive and neurophysiological mechanisms, among them the hearing attention.

The attention is present at daily basis, allowing to select which are the stimuli are important to perform the tasks. The hearing attention, specifically, is an individual skill to prepare himself, focus in a different stimulus at any time. It is an indispensable aspect to the acquisition of acoustic and phonetic aspects in linguistic patterns, essential in the process of reading and writing learning (4).

Since that the human ear has a limited capacity to process the arrival of stimulus (5), it is considered that the attentional mechanisms are important to limit the quantity of the processed information. Attentional processes concern of the determination of which internal and external stimuli are chosen to the processing, and consequently which stimuli will have an answer. Thus, the ability of attention shows itself as being of fundamental importance, in view of this ability requires to the listener chooses consciously which stimulus he will pay attention and will process the answer.

In view of the importance of parents participating on the identification and rehabilitation of changes presented by their sons, considering the importance of the ability of attention in acquisition of others important abilities for learning and, considering the emergency of scientifical works about this ability in the population with cleft lip and palate, I judge being necessary perform a retrospective study of the obtained answers from a relevant questionnaire about the ability of hearing attention in children with this malformation, in order to guide and diagnose as soon as possible of some present change, in future cases, establishing appropriate therapeutic measures.
This article has a goal to check the perception of the children parents with cleft lip and palate about the hearing attention of their children.

\section{MetHOD}

After the approval by the Ethics in Research Committee (Process number 13/2006), it was performed a retrospective study of children regularly enrolled in a hospital of São Paulo State, specialized in malformation.

The children selection was based in the following inclusion criteria:

a) Being in the range from 6 to 11 years-old.

b) Present any type of cleft lips and palate (7).

c) Do not present any genetic syndrome associated.

d) Enough parents understanding to answer to a questionnaire about the child's ability of hearing attention.

The children selection of control group, without the presence of cleft lips and palate.

The questionnaire applied about the skill of hearing attention consisted of three parts:

Part I - child identification, regarding his name, gender, age, address, degree and level of education, as well as the level of parental education.

Part II - hearing health, related to the positive history of hearing loss and ontological infections.

Part III - composed of 32 items related to attention: do not pay attention to the instructions $50 \%$ or more times; request frequently to repeat the instructions; say "ah"? and "what"? at least 5 or more times a day; not being able to pay attention to the hearing stimulus for more than few seconds; present short attention; dream awakened; be easily distracted by the background noise, having problems to sound discrimination; having problems in remember the sequence heard; forget what is told in a few seconds; have attention-deficit/ hyperactivity disorder (ADHD); taking medication for ADHD; often fails to give close attention to details makes mistakes in school activities, at work or others; having, with frequency, difficulties to keep the attention to ludic tasks or activities; seem, with frequency, do not listen when when spoken to directly.

To the experimental group 70 children participated being 44 of masculine gender and 26 of feminine gender. 
Participant of control group (without cleft lip and palate) 30 children being 15 of feminine gender and 15 of masculine gender who did not presented hearing complaint or disorders of the upper airway. As for the questionnaire to the parents / responsible for the children did not presented any hearing complaint related to hearing attention.

The Table 1 presents the distribution of the selected population. The control group was not inserted in this table.

\section{RESULTS}

As for obtained responses on the applied questionnaire (Hearing / Attention Questionnaire) (Appendix 1).

\section{Part I-Child identification, related to his} name, gender, age, address, schooling degree and level, as well as parents educational attainment.

Related to the gender, 44 are masculine gender and 26 feminine gender (Table 1).

Regarding to the children schooling, it was found that $19 \%$ are at Pre-school, $24 \%$ at first grade, $21 \%$ at second, $17 \%$ at third, $11 \%$ at fourth e $8 \%$ at fifth grade of basic education.

\section{Part II -Hearing health, positive story about the hearing loss and, ontological infections.}

The Table 2 shows the parents answers related to otitis media and hearing loss.

\section{Part III - Items related to attention.}

From a total of 70 medical records, from the 32 items, 27 was marked as the maximum quantity and 0 as minimum quantity with average as of 8,81 (dp 5,80).

On Table 3 we present the average results (x), percentage (\%) and standard deviation (sd), of questions of quantity marked by parents related to the gender, hearing loss history and history of middle ear infection of the child.

To correlate the age and quantity of the marked questions we used the correlation coefficient of Pearson
Table I. Participant distribution in the research with cleft lip and palate.

\begin{tabular}{lccccccc}
\hline $\begin{array}{l}\text { Age } \\
\text { Gender }\end{array}$ & 6 & 7 & 8 & 9 & 10 & I I & Total \\
\hline Masculine & 8 & 12 & 9 & 6 & 3 & 6 & 44 \\
Feminine & 7 & 3 & 4 & 5 & 3 & 4 & 26 \\
\hline Total & 15 & 15 & 13 & 11 & 6 & 10 & 70 \\
\hline
\end{tabular}

Table 2. Positive history of hearing loss and otologic infections.

\begin{tabular}{cccc}
\hline & YES(\%) & $\mathrm{NO}(\%)$ & TOTAL $(\%)$ \\
\hline Hearing Loss & $25(35,71 \%)$ & $45(64,29 \%)$ & $70(100 \%)$ \\
OMinfection & $50(71,43 \%)$ & $20(28,57 \%)$ & $70(100 \%)$ \\
\hline
\end{tabular}

Table 3. Correlation among marked questions and gender, presence of infection of middle ear and hearing loss.

\begin{tabular}{|c|c|c|c|c|c|c|}
\hline & \multicolumn{2}{|c|}{ Gender } & \multicolumn{2}{|c|}{$\begin{array}{c}\text { OM } \\
\text { Infection History }\end{array}$} & \multicolumn{2}{|c|}{$\begin{array}{c}\text { Hearing Loss } \\
\text { History }\end{array}$} \\
\hline & $M$ & $F$ & Yes & No & Yes & No \\
\hline $\begin{array}{l}\text { Average } \\
\mathrm{dp}\end{array}$ & $\begin{array}{l}9,34 \\
5,98\end{array}$ & $\begin{array}{l}7,92 \\
5,48\end{array}$ & $\begin{array}{l}8,82 \\
5,88\end{array}$ & $\begin{array}{l}8,80 \\
5,75\end{array}$ & $\begin{array}{c}10,20 \\
6,53\end{array}$ & $\begin{array}{l}8,04 \\
5,27\end{array}$ \\
\hline tvalue & & 988 & 0,01 & (NS) & 1,504 & (NS) \\
\hline P & & 327 & 0,990 & (NS) & 0,137 & (NS) \\
\hline
\end{tabular}

(significant correlation $\mathrm{p}<, 05000$ ) with result of 0,25 $(\mathrm{p}=, 034)$.

\section{DISCUSSION}

It was found after the analysis of the 70 children questionnaire with cleft lip and palate, that the major parents answered positively to the hearing disorder history: hearing loss ( 25 children) and occurrence of middle ear infection ( 50 children), having association to hearing loss and middle ear infection in 32 children.

On the researched literature it was found similar results $(8,9)$, and still researchers (10) who reported hearing disorders in children with cleft lip and palate.

Regarding to the comparison among historic presence of hearing loss related quantity of marked questions, the results show that there were no statistically significant difference between the groups. Research (11) refers that the FLP presents hearing disorder associated, this way, it was checked parents knowledge about hearing health of their children by elaborating and applying a relevant questionnaire in 100 parents of children with FLP, between 02 months and 05 years old. The authors 


\section{Appendix I. Questionnaire Hearing/Attention}

Part I Child Identification

Name:

Gender:

Date of birth:

Age:

Schooling degree:

Education level:

Parents' education level:

Address:

Part II Hearing Health

Hearing loss history. Affected ear: () RE () LE

Ear infection history. Which ear?

How many times?

Part III Child Attention

( ) Does not pay attention to the instructions $50 \%$ or more times

( ) Needs that the instructions be repeated many times

() Says "ah"? and "what"? at least 05 or more times a day

( ) Cannot pay attention to the auditory stimulus for more than few seconds

( ) Presents shortattention

( ) Dreamawakened

() Is easily distracted by background noise

( ) Has difficulties with phonemes

( ) Has problems with sound discrimination

( ) Has problems in rememberingthe sequence heard

() Forgets what is told in few seconds

( ) Do not rememberthe routine things, daily life

( ) Presents disorderandattention deficithyperactivity disorder(ADHD)

( ) Takes medicine for ADHD

( ) Frequently does not pay attention to the details or makes mistakes by carelessness in schoolactivities, work or others

( ) Withfrequency has difficulties in keeping attention intasks or recreational activities

( ) Withfrequency seems not listeningwhenspokento directly

( ) With frequency does notfollow the instructions and does not finishes the homework, housework or professional duties (not due to oppositional behavior or incapacity to understand the instructions)

() Withfrequency has difficulty to organize tasksandactivities

( ) With frequency avoids, dislikes or is reluctant to get involved in tasks which demands constant mental effort(such as homeworks or houseworks)

( ) With frequency loses necessary things to tasks of activities (for example, toys, homeworks, pencil, books and other materials)

( ) Is easily distracted by extraneous stimulifrom the task

() With frequency isforgetful in dailyactivities

() With frequency fidgets hands or feets or fumbles in the chair

( ) Frequently abandons his chairs in classroom or other situations in which is expected to remain seated

( ) Frequently runsaboutor climbs excessively, in situations in which is inappropriate

() With frequency has difficulty to play silently in leisure activities

( ) Isfrequently movingaround withoutstopping

( ) Frequentlytalks excessively

( ) Frequently blurts outanswers before questions have been completed

() Withfrequency has difficulty to waitfor his turn

( ) Frequently interrupts or intrudes on others matters 
concluded that parents have good knowledge about DA and its main manifestations, but they are not aware of hearing loss in children with FLP.

In a study performed (12) with 44 children with FLP of both genders aged between 08 and 14 years it was found by audiological evaluation and hearing process test that $22,8 \%$ presented some grade of hearing loss and $45,5 \%$ presented changed results in dichotic listening test, thus justifying, medical and audiological accompaniment to this population.

In comparison between presence of middle ear infection and the quantity of answers about auditory attention skills, the result was not significant. Researchers (13) in order to analyze the influence of otitis media on performance of children with complaint related to the auditory processing (PA) evaluated two groups of children aged between 06 to 13 years, being the group I constituted by 10 children with history of recurrent otitis media and with complaints related to the changes of PA, and the group II, composed of 15 children with complaint related to the PA changes and without history of recurrent otitis media. The author observed that children of both groups behaved themselves in similar way related to the measure of hearing abilities, not being found statistically significant difference between them in the behavioral tests of auditory sound localization, memory to verbal and non-verbal memories, speech in noise, dichotic digits, dichotic nonverbal and PSI in Portuguese.

Researchers (14) have found that children with FLP have significantly higher prevalence of otitis media with effusion than children without cleft. This result was found after longitudinal accompaniment of 05 years of audiological evaluation in 22 children with FLP aged between 1 e 5 years.

Authors (15) analyzed the prevalence of speech, language, hearing and dental disorders in children with diagnosis of FLP, through a retrospective revision of 95 patients with cleft lip (average 3,1 years-old). The results showed that $33 \%$ of those children presented effusion of OM and 13\% presented abnormal hearing. According to the obtained results from the application of the questionnaire to the parents, it was found that great part of the children presented behavior related to the difficulty as related to attention and impulsivity, as $88 \%$ of the interviewed parents marked at least one item contained in the questionnaire. Among the behaviors marked, what presented greater occurrence was "Talks excessively", present in $46 \%$ of the answered questionnaires, followed by the behaviors "Interrupts or intrudes on the others matters " (45\%), "Fidgets hands or feet or moves on the chair " (44\%), "Is easily distracted by a background noise "(41\%).
Asdescribed on the results, the questionnairesanswered by parents of children which formed the control group of this research did not marked none item referred to hearing complaint, this result different from that found in a study of researchers who (16) compared the judgment of parents with and without FLP related to the listening ability of their children, finding that both groups presented the same difficulties, however in children with cleft occurred with more frequency.

In a similar research the authors (17) observed that the patients with FLP presented similar behaviors to those who have hearing processing disorder (DPA), such result was obtained after parents of children with FLP answered to the Fisher questionnaire, with 25 items about the behavior found in those children with DPA and observed that $100 \%$ of the children with FLP showed some behavior indicative of DPA. In the relation of the questions marked and children age whose parents were interviewed was found significant statistically difference, may suggest that the greater the age the lower is the quantity of the questions marked by parents. The results show that the studied population, as the age advances, the presence of difficulties such as ability to hearing attention declines.

Many research have been using the questionnaire applied on the parents for a more careful investigation related to children with FLP $(10,11,18)$. This is important, as there are indications that the otitis media and the light hearing loss have as a consequence a delay in the language development in children (19), besides of the deficit of processing and hearing attention (20).

\section{CONCLUSION}

It was not observed statistically difference between the number of the marked items by parents on the questionnaire and the positive history of hearing loss and middle ear infection.

Most of the parents identified at least a of the behaviors related to the attention contained in the questionnaire, showing the that presence of cleft lip and palate can be related to the difficulties of hearing attention.

\section{BiBLIOGRAPHICAL REFERENCES}

1. Amaral MIR, Martins JE, Santos MFC. Estudo da audição em crianças com fissura labiopalatina não-sindrômica. Braz J Otorhinolaryngol. 2010, 76(2):164-71.

2. Goudy S, Lott D, Canadyj, Smith RJ. Conductive hearing loss and otopathology in cleft palate patients. Otolaryngol Head Neck Surg. 2006, 134(6):946-8. 
3. Wyszynski DF. Cleft Lip \& Palate: from origin to treatment. New York, Oxford. University Press, 2002.

4. Gomes H, Molholm S, Christodoulou C, Ritter W, Cowan $\mathrm{N}$. The development of auditory attention in children. Front Biosci. 2000, 5: D108-20.

5. Windsor J, Hwang M. Children's auditory lexical decisions: a limited processing capacity account of language impairment. J Speech Lang Hear Res. 1999, 42:990-1002.

6. Medwetsky L. Central auditory processing. In: Katz J, Burkard RF, Medwetsky L, editors. Handbook of clinical audiology. Baltimore: Williams Wilkins; 2002. p.495-509.

7. Spina V, Psillakis JM, Lapa FS, Ferrari MC. Classificação das fissuras labiopalatinas: sugestão de modificação. Rev Hosp Clín Fac Med São Paulo. 1972, 27(1):56.

8. Hocevar B, Jarc A, Kozelj V. Ear, nose and voice problems in children with orofacial clefts. J Laryngol Otol. 2006, 120(4):276-281.

9. Yang F, McPherson B, Shu H. Evaluation of an Auditory Assessment Protocol for Chinese Infants with Nonsyndromic Cleft Lip and/or Palate. Cleft Palate Craniofac J. 2010 May 12.

10. Sheahan P, Miller I, Sheahan JN, Earley MJ, Blayney AW. Incidence and outcome of middle ear disease in cleft lip and/or cleft palate. Internat J Pediat Otorhinolaryng. 2003, 67(7):785-793.

11. Bosso JR, Feniman MR, Spinardi ACP, André KD, PiazentinPenna SHA. Conhecimento dos pais a respeito da saúde auditiva de seus filhos portadores de fissura labiopalatina. In: 11ํㅗำósio Internacional de Iniciação Cientifica da USP SIICUSP, 2003, Ribeirão Preto. Anais do $11^{\circ}$ Simpósio Internacional de Iniciação Cientifica da USP SIICUSP.
12. Amaral ML, Martins JE, Santos MF. A study on the hearing of children with nonsyndromic cleft palate/lip. Braz J Otorhinolaryngol. 2010, 76(2):164-171.

13. Santos MFC, Ziliotto KN, Monteiro VG, Hirata CHW, Pereira LD, Weckx LLM. Avaliação do processamento auditivo central em crianças com e sem antecedentes de otite média. Rev Bras Otorrinol. 2001, 67(4):448-454.

14. Flynn T, Möller C, Jönsson R, Lohmander A. The high prevalence of otitis media with effusion in children with cleft lip and palate as compared to children without clefts. Int J Pediatr Otorhinolaryngol. 2009, 73(10):1441-6.

15. Vallino LD, Zuker R, Napoli JA. A study of speech, language, hearing, and dentition in children with cleft lip only. Cleft Palate Craniofac J. 2008, 45(5):485-94.

16. Barufi L. Comportamento de escuta em indivíduos com fissura labiopalatina: achados preliminares. J Bras Fono. 2004, 5(19):9-15.

17. Minardi CG, Souza AC, Netto MP, Ulhôa FM, Feniman MR, Campos CF, et al. Auditory abilities in children with cleft lip and/or palate according to Fishers. Acta Otorrinolaringol Esp. 2004, 55(4):160-164.

18. Nicolielo AP, Feniman MR. A fala, linguagem e processamento auditivo na fissura labiopalatina, segundo o questionário proposto por YLIHERVA. Rev Soc Bras de Fono. 2004, 9, Suplemento especial.

19. Roberts J, Hunter L, Gravel J, Rosenfeld R, Berman S, Haggard M, et al. Otitis media, hearing loss, and language learning:controversies and current research. J Develop Behavior Ped. 2004, 25(2): 110-122.

20. Lemos ICC, Ribeiro MF. Teste de Habilidade de Atenção Auditiva Sustentada em crianças de sete anos com fissura lábio palatina. Rev Bras Otorrinolaringol. 2010, 76:199-205. 